\title{
Capsule Commentary on Ogunbayo et al., "Treatment Bias in Management of HIV Patients Admitted for Acute Myocardial Infarction: Does it Still Exist?"
}

\author{
Ahmed Taha, MDe \\ Department of Internal Medicine, Deaconess Hospital, Evansville, IN, USA.
}

J Gen Intern Med 35(1):399

DOI: $10.1007 / \mathrm{s} 11606-019-05499-1$

(c) Society of General Internal Medicine 2019

$\mathrm{T}$ he national cohort study by Ogunbayo et al. ${ }^{1}$ compared the prevalence of revascularization (percutaneous coronary intervention $[\mathrm{PCI}]$ or coronary artery bypass graft $[\mathrm{CABG}]$ ) in patients with acute myocardial infarction (AMI) who were seropositive for human immunodeficiency virus (HIV) to those who weren't. The investigators also tested allcause inpatient mortality and length of stay in the two groups. The authors extracted admissions (patients) from the National Inpatient Sample database during the years 2010-2014.

How a patient's HIV status affects the standard of care for AMI has always been a matter of scientific debate. In the early 2000s, it was noted that AMI was managed more conservatively, with significantly lower rates of revascularization, in HIV patients than in the general population. ${ }^{2}$ Smilowitz et al. reported, however, an uprising trend of revascularization in HIV patients (42\% in 2002 to $63 \%$ in 2011; $P$ value $<0.001){ }^{3}$ Ogunbayo et al. emphasized that patients with HIV infection are no longer at a treatment disadvantage, as there was no treatment bias with respect to HIV status noted in terms of revascularization during the years 2010-2014. It is impossible, though, to ascertain from the study of Ogunbayo et al. whether the comparable revascularization rate, regardless of HIV status, represented a higher quality of treatment than in the past.

Despite AMI occurring at a younger age in HIV patients, possibly due to ongoing activation of the immune system and exposure to pro-atherogenic highly active antiretroviral therapy, ${ }^{4}$ incidence of cardiovascular-related deaths in HIV populations is declining $(20 / 100,000$ people in 2002 to $16 / 100,000$ people in 2016). ${ }^{5}$ The population-based cohort of Ogunbayo

Published online October 28, 2019 et al., consisting of the US population during 2010-2014, highlighted the absence of independent association between HIV infection and in-hospital mortality or length of stay, coinciding with existing literature. It is unclear, though, whether the comparable revascularization rate, regardless of HIV status, contributes to the decreased in-hospital mortality, length of stay, and cardiovascular-related deaths in HIV patients, or if this AMI management bias, if persistent, would translate to an appreciable in-hospital mortality difference. Further clinical studies are needed to validate these observations.

Corresponding Author: Ahmed Taha, MD; Department of Internal Medicine Deaconess Hospital, Evansville, IN, USA (e-mail: aaataha1@gmail.com).

\section{Compliance with Ethical Standards:}

Conflict of Interest: The author declares that he does not have a conflict of interest.

\section{REFERENCES}

1. Ogunbayo G, Ha LD, Ahmad Q, et al. Treatment Bias in Management of HIV Patients Admitted for Acute Myocardial Infarction: Does it Still Exist? JGIM. https://doi.org/10.1007/s11606-019-05416-6.

2. Pearce D, Ani C, Espinosa-Silva Y, et al. Comparison of in-hospital mortality from acute myocardial infarction in HIV sero-positive versus sero-negative individuals. Am J Cardiol. 2012;110(8):1078-1084. https:// doi.org/10.1016/j.amjcard.2012.05.045.

3. Smilowitz NR, Gupta N, Guo Y, Coppola JT, Bangalore S. Influence of Human Immunodeficiency Virus Seropositive Status on the In-Hospital Management and Outcomes of Patients Presenting With Acute Myocardial Infarction. J Invasive Cardiol. 2016;28(10):403-409.

4. Currier JS. Update on cardiovascular complications in HIV infection. Top HIV Med Publ Int AIDS Soc USA. 2009;17(3):98-103.

5. 17-3-98.pdf. https://www.iasusa.org/wp-content/uploads/2009/07/173-98.pdf. Accessed 25 Sept 2019.

Publisher's Note Springer Nature remains neutral with regard to jurisdictional claims in published maps and institutional affiliations. 